\title{
Decolonization and Restorative Justice: A Proposed Theoretical Framework
}

\author{
Muhammad Asadullah ${ }^{1}$
}

\begin{abstract}
The concept of decolonization has been used in numerous disciplines and settings, including education, psychology, governance, justice, transitional justice, restorative justice as well as research methods. Fanon (1963) saw decolonization as a process of both unlearning and undoing the harms of colonization. For Monchalin (2016), decolonization is both a goal and process to bring about a fundamental shift in colonial structures, ideologies and discourses. According to Alfred (2009, p. 185), decolonization requires "nation-to-nation partnership" for "justice and peace". In the context of Restorative Justice (RJ), decolonization entails a) addressing historical harms of colonization, b) recognizing grievances of Indigenous and marginalized communities about the justice system as genuine, and c) acknowledging that state- or INGO-funded RJ practices may do more harm than good. This paper begins with a brief overview of decolonization discourses from both micro and macro perspectives to then locate decolonization in justice settings, arguing against 'copying and pasting' Eurocentric models of RJ practices. Grounded in the findings of RJ visionaries and practitioners in Bangladesh and the work of Cunneen (2002), and Tauri and Morris (1997), this study proposes a decolonizing framework for RJ practices.
\end{abstract}

Keywords: decolonization, restorative justice, consultation, cultural relevancy, resource sharing

\footnotetext{
${ }^{1}$ University of Regina, Regina, Saskatchewan, Canada
} 


\section{Introduction}

The notion of decolonization has been used in numerous disciplines and settings including education (Paris \& Winn, 2014), psychology (McNamara $\&$ Naepi, 2018), governance and justice (Monchalin, 2016; Stewart, 2018), transitional justice (Matsunaga, 2016), restorative justice (RJ) (Cunneen, 2002; Park, 2016; Tauri \& Morris, 1997), criminology (Blagg, 2008; Carrington et al. 2016) as well as research methods (Bhattacharya, 2018; Smith, 2012). The concept has generated a plethora of definitions. In Fanon (1963), decolonization is a violent process of unlearning and undoing the harms of colonization. For Monchalin (2016), decolonization is a goal and process to bring about a fundamental shift away from colonial structures, ideologies, and discourses. According to Alfred (2009, p. 185), decolonization requires "nation-to-nation partnership" for "justice and peace". Chief Robert Joseph, Hereditary Chief of the Gwawaenuk First Nation (British Columbia, Canada) emphasizes the importance of relationship-building: "Let us find a way to belong to this time and place together. Our future, and the well-being of all our children rests with the kind of relationships we build today" (Reconciliation Canada, n.d). For RJ, decolonization 1) addresses historical harms of colonization (Stewart, 2018), 2) recognizes genuine grievances of Indigenous and marginalized communities about the justice system (Cunneen, 2002), and 3) acknowledges that state- or INGO-funded RJ practices may do more harm than good (Strang \& Sherman, 2015). A decolonizing methodology for RJ engages the local, Indigenous and marginalized communities to "formulate and activate processes that derive from their own particular traditions and conditions" (Cunneen, 2002, p. 42).

This paper begins with a brief overview of decolonization discourses from micro and macro perspectives and locates decolonization in justice settings - Bangladeshi justice in particular - arguing that 'copying and pasting' a Eurocentric model of RJ practice into the Bangladeshi justice system would be problematic. More importantly, this paper critically reviews findings of the development of RJ in Bangladesh. Both in-depth qualitative interviews and survey instruments were employed in the study, which is grounded in the findings of research participants and the work of Cunneen (2002), Monchalin (2016), and Tauri and Morris (1997). A decolonization model for RJ practices, particularly for use in Bangladesh, is conceptualized by a tree structure having four key components: 1) roots, 2) trunk, 3) branches, and 4) fruits. The roots forge a trauma-informed, anti-oppressive foundation. Key tasks for 'root' development are active listening and 
consultation. The trunk embodies local knowledge and leadership, and its key task is relationship building. Branches represent culturally and socially relevant justice practices across similar settings. The 'fruit' of this 'Decolonizing Framework for RJ' is the emergent knowledge. In other words, this study assumes that the adoption of a trauma-informed approach and anti-oppressive framework involving the leadership of local justice stakeholders coupled with lessons from the promising practices across somewhat similar cultural settings would result in more socially and culturally aligned RJ practices in Bangladesh.

\section{Literature Review}

\section{Overview of Decolonization}

The definition of decolonization varies among scholars. Some take a macro view, decolonization through institutional or societal changes (Alfred, 2009; Jacobs, 2017; Tuck \& Yang, 2012), others take a micro approach decolonization of mind and intellect (Cunneen, 2002; Park, 2016). However, Monchalin (2016) and Bird (2014) believe decolonization encompasses shifts on both macro and micro levels. The term 'decolonization' was coined by Henri Fonfrède in early 1836 and used by social scientists since the 1920s. In the 1950s, for example, the term was used to critique the French imperial system that colonized many parts of the world (Shepard, 2006).

Frantz Fanon's seminal work Wretched of the Earth - which is the "Bible of decolonisation" for Stuart Hall (cited in Etherington, 2016, p. 153) - provides a comprehensive outline for the decolonization process. Influenced by Sartre's 'dialectical reason', Fanon argues that decolonization is a process through which "the colonized liberate themselves politically and psychologically" (Etherington, 2016, p. 156). Like the colonial system, decolonization will not happen by magic, happenstance or friendly agreement. Fanon identified three forms of decolonization - intellectual, psychological and physical - and declared decolonization a process of complete disorder. Decolonization is a historical process, which is to say "it cannot be understood, it cannot become intelligible nor clear to itself except in the exact measure that we can discern the movements which give it historical form and content" (Fanon, 1963, p. 36). Additionally, decolonization is also seen as "an action taken by the colonized upon the colonizer" (Etherington, 2016, p. 157). This study categorizes the concept of 
decolonization into micro and macro forms. Micro aspects focus on mind, body, language, culture, and ceremonies, while macro forms involve structural and institutional change.

\section{Micro Forms of Decolonization}

Decolonization of mind and body informs the micro perspective, which also entails the restoration of language. According to Fanon (1963), decolonization of the mind lays a resilient foundation that rejects "imitation [and] mimicry" (p. 311) but upholds creativity and imagination. Ngũgĩ wa Thiong'o's seminal work Decolonising The Mind: The Politics of Language in African Literature (1986) argues that the process of decolonizing the mind can lead to healing. Destruction of local language and imposition of the colonizer's language was a tactic of the colonial system, making language restoration an important part of decolonization. For Thiong'o, decolonizing the mind and restoration of language lead to re-centring and healing (Ngũgi, 1986). The concept of "neurodecolonization", coined by Dr Michael Yellow Bird of North Dakota's Arikara and Hidatsa Nations, theorizes decolonization of the mind as a process of freeing "ourselves from post-colonial culture and thought, from dependence on Western ideas, philosophies, beliefs, and theories" (cited in Monchalin, 2016, p. 294). Yellow Bird (2014) emphasizes that the healing and decolonization of minds and actions through neurodecolonization can manifest in a decolonized ethos. Blagg (2008), Cunneen (2002), and Regan (2010) argue along the same lines.

Decolonization also means the restoration of cultures, ceremonies, and praxis. Michael Yellow Bird emphasizes that culture and ceremonies are considered medicine for Indigenous Peoples, identifying decolonization as a process of "restoration of cultural practices, thinking, beliefs and values" (cited in Monchalin, 2016, p. 293). According to Manuel (2017), learning from the Elders about Indigenous justice systems is key to decolonization. Laboucan-Massimo (2017) argues for a more personal decolonization integrated into daily life because values such as respect, trust, and humility are integral not only to political change but to everyday relations (LaboucanMassimo, 2017). Other microforms of decolonization include the restoration of singing, drumming, and traditional teachings, which an Indigenous DJ group, 'A Tribe Called Red', has been echoing around the world (Monchalin, 2016, p. 297). Finally, micro decolonization can also mean upholding "resiliency" in the face of challenges, trials, and tribulations (Jacobs, 2017, p. 51). 


\section{Macro Form of Decolonization}

Several scholars define decolonization from the macro perspective by addressing institutional and systematic change, such as self-governance, wealth redistribution, and policy reform (Fanon, 1963; Monchalin, 2016). Jacobs (2017) sees decolonization as Indigenous communities "retaking the power" (p. 50) - social, economic and political power. Others articulate decolonization as self-governance, land expropriation, and restitution (Alfred, 2009). Tuck and Yang (2012) view colonization as an "entangled triad structure of settler-native-slave" (p. 1) and decolonization as a disruption of the colonial structure. The macro aspect of decolonization requires a systemic institutional change of public services, from education to government.

McNamara and Naepi (2018) propose indigenization as an important step in changing the system and posit policies and actions adopted by different school districts and universities across Canada as decolonizing indigenization (McNamara and Naepi, 2018). Battiste (2013), in Decolonizing Education: Nourishing the Learning Spirit, argues that "[t]he education system has not yet ensured that non-Indigenous children develop an accurate understanding of the Indigenous peoples in Canada and their knowledge systems" (p. 32), yet this is a critical act of any decolonization. Some scholars (Alfred, 2017; Jacobs, 2017; Manuel, 2017) argue "massive transfer of land back to the Indigenous peoples" must also occur for decolonization (Alfred, 2017, p. 13), because land is sacred within Indigenous spirituality (Sellars, 2017, p. 6). Tuck and Yang (2012) also echo that "decolonization in the settler colonial context must involve the repatriation of land" (p. 7).

In summary, micro and macro forms of decolonization are interconnected. Microforms of decolonization address epistemic violence, finding new definitions and reclaiming language, ceremonies, and culture. Macroforms of decolonization involve land repatriation as well as systemic and institutional changes.

\section{Decolonization and the Criminal Justice System}

A decolonizing lens critically examines the development of the criminal justice system. Blagg and Anthony (2019) view that RJ practices are "fundamentally different" (p.133) from Indigenous Justice practices. Tauri (2016) argues that global restorative movements, especially family group 
conferencing $(\mathrm{FGC})$, in many ways resulted in the "commodification" of Indigenous peoples and culture (p. 52). According to Breton (2011), a decolonizing lens in RJ must ask different sets of questions which include: What happened in our history on this land? Who as a people was hurt and continues to be hurt? And who as a people caused the hurt and continues to benefit from it?

The criminal justice system from a decolonization lens first evokes a recognition that the creation of a criminal justice system for the colony was instrumental to the colonial project (Stewart, 2018). Secondly, Indigenous and marginalized communities around the world have genuine reasons to be skeptical about government-supported criminal justice practices and interventions (Park, 2016), as evidenced by formal and informal practices, such as racial profiling and police "starlight tours" (Stewart, 2018. p. 185). Thirdly, government-led RJ practices may result in additional harm. Tauri (1999) offers examples showing that New Zealand's FGC model for government-led RJ "fails to confirm that it empowers its Indigenous population" (p. 159). Strang and Sherman (2015) also exemplify harm by RJ especially for Aboriginal people in Australia: "The [RJ] experiment tells us that more victims were harmed, and offenders descended further and faster into crime when RJ conferences were used with [Aboriginal people] instead of prosecution in court" (Strang \& Sherman, 2015, p. 10). Finally, because of colonial-engrained power imbalance and unintended harms, a traumainformed approach, which is not consistently present in RJ practices, is necessary for the decolonization of the justice sphere.

In summary, a decolonizing lens acknowledges 1 ) the colonial context of the criminal justice system, 2) the institutional power imbalance between justice stakeholders and Indigenous or other marginalized communities, 3) that government-led RJ may contribute more harm, and 4) the need for a trauma-informed approach.

\section{Decolonization and RJ}

RJ practices have been expanding across the world since around 1974. Some RJ practices have grown locally in consultation with local community justice stakeholders. Pukhtoon Jirga in Pakistan is one of these (Yousufzai \& Gohar, 2005). However, some RJ practices emerged without proper local consultation, especially in Australia (Blagg, 1997; Cunneen, 1997) and New Zealand (Tauri, 1999; Tauri \& Morris, 1997). Therefore, from a decolonizing lens, RJ is viewed as "a modernist, Euro-American concept concerned with 
reforming what remains an essentially Western approach to justice" (Blagg (2017, p. 61). Blagg (2017) further argues that RJ failed to address the justice needs of Indigenous peoples, especially in Australia. More seriously, several scholars cautioned RJ practitioners from confusing RJ with Indigenous justice practices (Hand, Hankes \& House, 2012; McGuire \& Palys, 2020). McGuire and Palys (2020) argue that "Canada has attempted to 'fix' this problem through creating parallel systems, trying to fit 'Indigenous' conceptions of justice into existing systems, and problematically adopting restorative justice as synonymous with Indigenous justice" (p. 59).

\section{Decolonization and $R J$ in Bangladesh}

$\mathrm{RJ}$ as a concept and practice was formally introduced in Bangladesh in 2013. Several factors contributed to the emergence of RJ in Bangladesh. Legal case backlogs; active engagement of civil society organizations, such as Madaripur Legal Aid Association; and support from INGOs, such as GIZ Bangladesh, all played a significant role. The establishment of the Madaripur Legal Aid Association was important to the needed (re)structuring of community-based salish practices in Bangladesh following independence. GIZ Bangladesh played the most instrumental role in the growth of RJ in Bangladesh by formally launching RJ in 2013. Later, the Activating Village Court Project of the United Nations Development Programme and the establishment of the Victimology and Restorative Justice graduate programme at the University of Dhaka contributed to the expansion of RJ in Bangladesh (Asadullah, 2020; Asaduzzaman, 2014, GIZ, 2014; The Daily Star, 2015).

Scholars, especially in Australia and New Zealand, have examined RJ and decolonization using the following common themes as a framework: consultation, cultural relevancy, and resource-sharing (Cunneen, 2002; Park, 2016; Tauri \& Morris, 1997). In Bangladesh, however, there is almost no literature addressing $\mathrm{RJ}$ from a decolonizing lens. It is against this background that this study seeks to explore the concept of decolonization and $R J$ in Bangladesh. 


\section{Research Method}

This study employed a qualitative research method. Braun and Clarke (2013) define a qualitative method as exhibiting both techniques and frameworks of data collection. They also describe it as a paradigm that has a specific belief, assumption and practice. Denzin and Lincoln (2013) view qualitative methods as an interpretive and naturalistic mode of inquiry. According to them, in qualitative methods, researchers "study things in their natural settings, attempting to make sense of or interpret phenomenon in terms of the meanings people bring to them" (p. 7).

\section{Research Question}

Qualitative inquiry grounds research questions in the experiences of research participants and tends to ask 'how' instead of 'why' (Braun \& Clarke, 2013). The research question here is: How is the decolonization of $\mathrm{RJ}$ operationalized in Bangladesh?

\section{Sampling and Research Participants}

Gentles et al. (2015) define sampling in qualitative research as "the selection of specific data sources from which data are collected to address the research objectives" (p. 1777). With the snowball sampling method, the researcher gains access to participants through other participants. This research employed both the purposive and snowball sampling method. Purposive sampling is differentiated from snowball sampling by allowing the researcher to recruit participants based on their relevancy to the study (Yin, 2011). The researcher (this author) was invited to the $1^{\text {st }}$ International Conference on Restorative Justice held in Bangladesh in 2015. During the conference, the researcher met academics, practitioners and government officials from across Bangladesh (BD). Many conference attendees shared their business cards with the researcher. The first three key informant interviewees in BD were recruited via the social capital of the researcher and the rest of the research participants were selected using the 'snowball sampling technique'. In total, this research included six key informant interviewees. Participation was voluntary and unpaid. Pseudonyms (e.g., BD 1) were used to ensure confidentiality. 


\section{Table 1. Key-Informant Interviewees' Backgrounds}

\begin{tabular}{|l|l|l|}
\hline Pseudonym & Research Site & Professional Background \\
\hline BD 1 & Bangladesh & Academic Institution \\
\hline BD 2 & Bangladesh & INGO (International Non-government Organization) \\
\hline BD 3 & Bangladesh & CBO (Community Based Organization) \\
\hline BD 4 & Bangladesh & INGO \\
\hline BD 5 & Bangladesh & CBO \\
\hline BD 6 & Bangladesh & INGO \\
\hline
\end{tabular}

\section{Survey Participants}

Along with in-depth qualitative interviews, a survey was also employed for data collection. Via the platform SurveyMonkey, a hyperlink was emailed to the executive directors and programme coordinators of several communitybased justice practices. Two weeks after the initial email, and a week before the survey deadline, a reminder email was sent to all prospective participants. To maintain anonymity, no identifiable information was collected in the survey. Survey participants, selected from the websites of RJ organizations in Bangladesh, were older than 19 and from diverse backgrounds (academic, government, NGO, INGO and CBO). In total, 22 survey respondents participated in this study.

\section{Decolonization and Research Methods}

Decolonization of research methods has been addressed and discussed by several scholars who recognize how the history of colonization has interconnected with research (Bhattacharya, 2018; Ninomiya et al., 2018; Paris \& Winn, 2014; Smith, 2012; Smylie et al., 2015). One of the earliest works in decolonizing research methodology was by Dr Linda Tuhiwai Smith. Smith (2012) explains decolonizing methodology from an Indigenous worldview. Her work is grounded in the seminal works of Fanon (1963) and Said (1978). Critically examining the colonial history of researchers with Indigenous peoples, Smith (2012) argues that deconstructing contemporary knowledge and recreating new knowledge is a process of decolonization, but that deconstruction alone is not sufficient. She (2012, p. 3) articulates that: 
In a decolonizing framework, deconstruction is part of a much larger intent. Taking apart the story, revealing underlying texts, and giving voice to things that are often known intuitively does not help people to improve their current conditions.

For Paris and Winn (2014), the goal of decolonizing critical inquiry (i.e., decolonizing the method) is to humanize research. Through participation, collaboration, and dialogic consciousness-raising, research participants experience what it means to "feel valued" and the researcher engages in "worthy witnessing" instead of neutral observing ( $p$. xiv). The person-to-person connection - built through formal and informal interactions - allows researcher and research participants to experience one another's humanness. Contrary to the colonial up-down relationship between researchers and research participants, this humanizing process makes them co-creators of knowledge.

Ninomiya and colleagues (2018) also argue that epistemological and methodological shifts are necessary to decolonize research. Epistemological shifts affect how knowledge is gathered, produced and shared. Methodological shifts involve acknowledging the failings of colonial research methods, reconfiguring the researcher-participants relationship, becoming mindful of power imbalances, and refocusing on collaboration and partnership (Ninomiya et al., 2018). Bhattacharya (2018) locates assumptions of researcher superiority in colonial inquiry methods and emphasizes the need for a "very deep, collaborative, respectful relationship" with research participants (p. 3). Researchers no longer "study on the participant"; they engage in a collaborative approach that brings humility and connection into practice. Mindfulness of the colonial power imbalance keeps researchers focussed on the participants rather than on the expectations of academic publishers (Bhattacharya, 2018).

In the light of the above findings, this study employed three elements of decolonization of methods: researcher as facilitator and collaborator, (b) a favouring of emotion, and (c) mindfulness of power imbalance.

During key informant interviews, the researcher provided a safe, supportive space for sharing. The nature of the questions, such as "I am curious to learn about your Restorative Justice journey", made research practitioners less prone to sharing personal stories. The researcher's role was active listening and facilitator. 
The researcher welcomed the expression of sadness and joy when key informant interviewees shared their personal RJ journeys. According to McMillan (2018), allowing research participants to express sadness, joy, and tears helps build rapport. Kvale and Brinkman (2009) explain possible therapeutic impacts on research participants through "emotional personal interaction" (p. 41).

The researcher was mindful of power imbalances between himself and the research participants, particularly during his fieldwork in Bangladesh. In this vein, the researcher a) interviewed research participants in their preferred language or dialect, b) proposed co-authorship for future publications, and c) participated in food sharing - a culturally valued practice.

\section{Findings and Discussions}

The concept of decolonization in relation to $R J$ has been raised by several scholars (see Cunneen 1997, 2002, 2006; Tauri, 1998, 1999, 2016; Park, 2016). Their decolonization lens for RJ in Australia and New Zealand brought some common themes such as consultation, cultural relevancy, and resource sharing into view. The following section details these themes, particularly in relation to the development of $\mathrm{RJ}$ in Bangladesh. Building on the findings from its interviews and surveys, this study finds that as RJ was introduced in Bangladesh, there was limited consultation with local Bangladeshi stakeholders and poor resource sharing of texts written in Bengali. These challenges threw the cultural relevancy of the RJ into question. The next section reveals those findings in detail.

\section{Consultation}

Meaningful consultation is primordial in a decolonizing framework for RJ. The notion of meaningful consultation varies; however, while each nation and each community has its cultural protocols, customs, and traditions around meaningful consultation, all consider guidance from Elders, local community members and villagers to be the starting point (Goulding et al., 2016).

In his examination of family group conferencing (FGC) in Australia, Cunneen (1997) identifies a significant gap in consultation and negotiation with Indigenous peoples and Elders. This concern echoes Dodson (1996) who 
is scathingly critical of the development process of diversionary programmes like FGC:

Diversionary programmes are frequently rigid in their structure [...] they are not designed in close consultation with indigenous communities [...] They are packaged in remote 'policy' units and driven or posted into communities. We see diversion delivered to us in a package because 'they' know what is best for 'us'. The paternalism of such diversion reflects the earlier policies of 'care and protection' and 'assimilation' that permitted the removal of indigenous children from their families up until the 1970s (p. 31).

As a result of the lack of consultation and negotiation, the development of RJ, especially FGC in Australia, fails to capture what is needed for Aboriginal peoples (Cunneen, 1997), and the one-size-fits-all approach added to the challenges (Dodson, 1996). The implementation of RJ without appropriate consultation also contradicts the recommendations of the Royal Commission into Aboriginal Deaths in Custody (1987), for example, Recommendation 62's explicit need to establish an intervention that includes discussion and negotiations with Aboriginal peoples. Meaningful consultations would have made FGC more successful in Australia (Cunneen, 1997; Dodson 1996).

Consultation or the lack thereof with Māori Elders and communities was similarly questioned in New Zealand, and its signature FGC model came to be seen as "an extension of the State's biculturalisation project into the arena of criminal justice" (Tauri, 1999, p. 159). The lack of consultation with Māori people in the development of alternatives like the FGC (Tauri \& Morris, 1997, p. 151) led Tauri (2016) to challenge its Māoriness.

In the context of Bangladesh, this present study finds that consultation with local community-based justice experts from salish practices was minimal. Informal consultation involved INGOs, government officials, and some CBOs. A key objective of the meaningful consultation process is to listen and get guidance in the aim of preventing further harms. In her celebrated work, Do No Harm, Anderson (1999) shows projects funded and supported by INGOs do more harm than good given a lack of such consultation. One interviewee in the present study, BD 6, maintained that there had been some consultation: that GIZ Bangladesh conducted a "feasibility study", consulted with partner NGOs, and hosted "stakeholder 
engagement" sessions with CBOs and local communities. However, BD6 had no specific information about the types of consultation. In contrast, two other key informant interviewees, BD 3 and BD 4, both having leadership roles in community-based justice practices, stated that consultation was limited.

BD 3 added that the consultation process with local communities was not

meaningful at all. We should not call it consultation or meaningful engagement because INGOs already had set agenda and financial resources on what they wanted to do. It hardly matters what local community says.

BD 3 went on to say that even if there were consultation and engagement, usually only NGO officials from selected organizations got the invite: "Most of the engagements and consultations were not open to [the] general public". BD 4 also expanded on the minimal consultation with local communities, using the Bengali word for consultation, poramorsho, to emphasize that

generally, people are willing to receive poramorsho [consultation]. I don't think there was any formal consultation with local justice experts.

The majority of survey participants (see Figure 1) likewise shared that consultation between local community justice leaders and experts, such as from the salish practices, during the implementation of RJ in Bangladesh was limited. Almost 59\% of survey participants observed a little consultation during the implementation of RJ in Bangladesh, while 12\% saw none. 
Figure 1. Opinion on consultation with local community justice leaders and experts such as experts of Salish during the implementation of $\boldsymbol{R J}$ (survey findings)

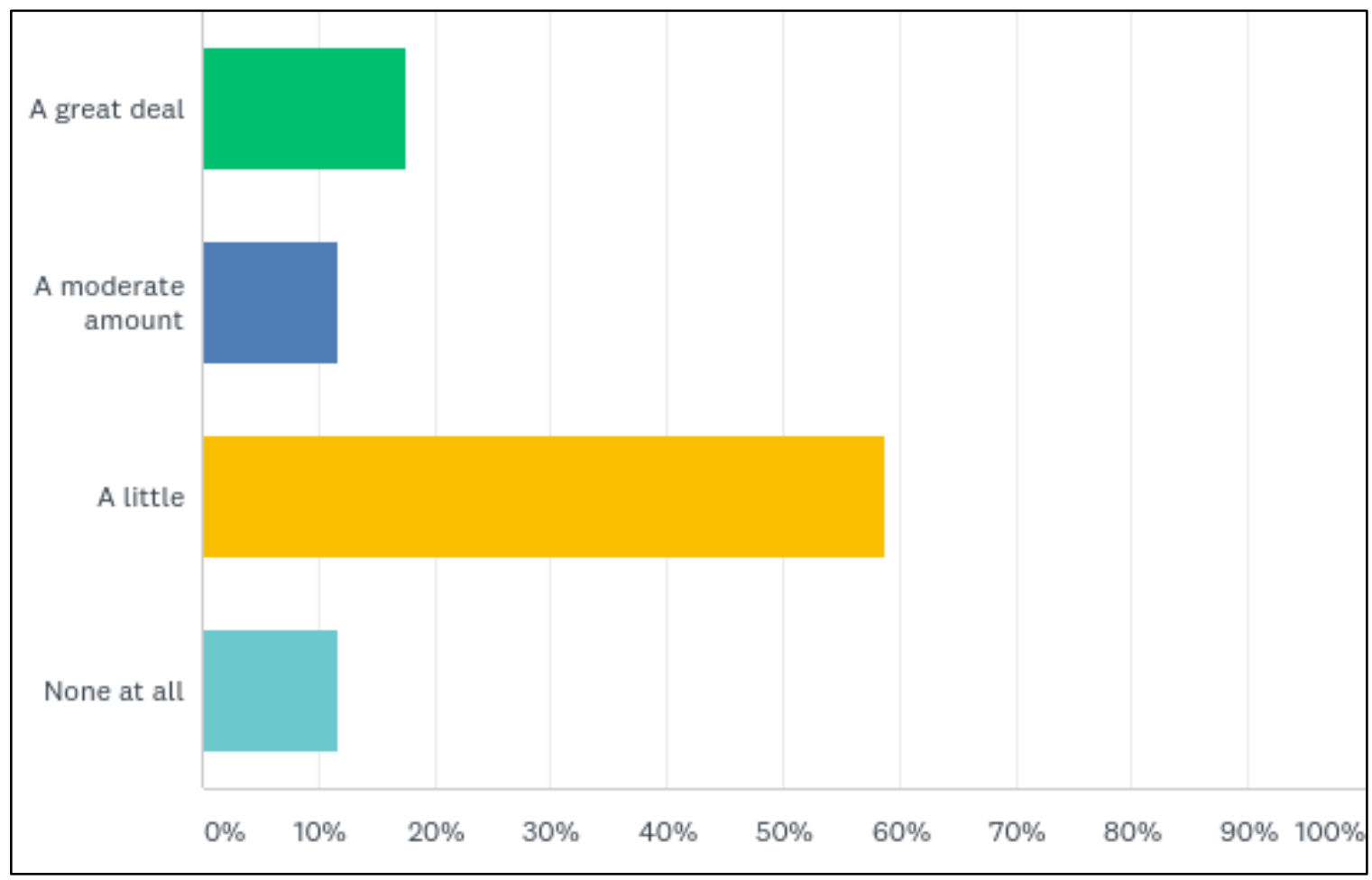

This study also finds a lack of consultation with local Indigenous communities and Elders still practicing customary laws and justice. BD 5 considered it a "lost opportunity":

Indigenous justice systems are the most neglected form of informal justice process. $R J$ practices can hugely benefit from these practices, especially from the 13 tribes in CHT [Chittagong Hill Tracts]. I don't know why RJ practitioners did not invite or even consult with Indigenous communities in Bangladesh. I think it is a lost opportunity. Still, there is time for INGOs and NGOs to consult with Indigenous leaders. RJ practices in Bangladesh will certainly get better in this way.

Survey participants (see Figure 2) echoed these sentiments. Almost $52 \%$ think there was little consultation with Indigenous Elders and communities, whereas less than $18 \%$ perceived a moderate amount. 
Figure 2. Opinion on consultation with Indigenous Elders during the implementation of $\boldsymbol{R} J$ in Bangladesh (survey findings)

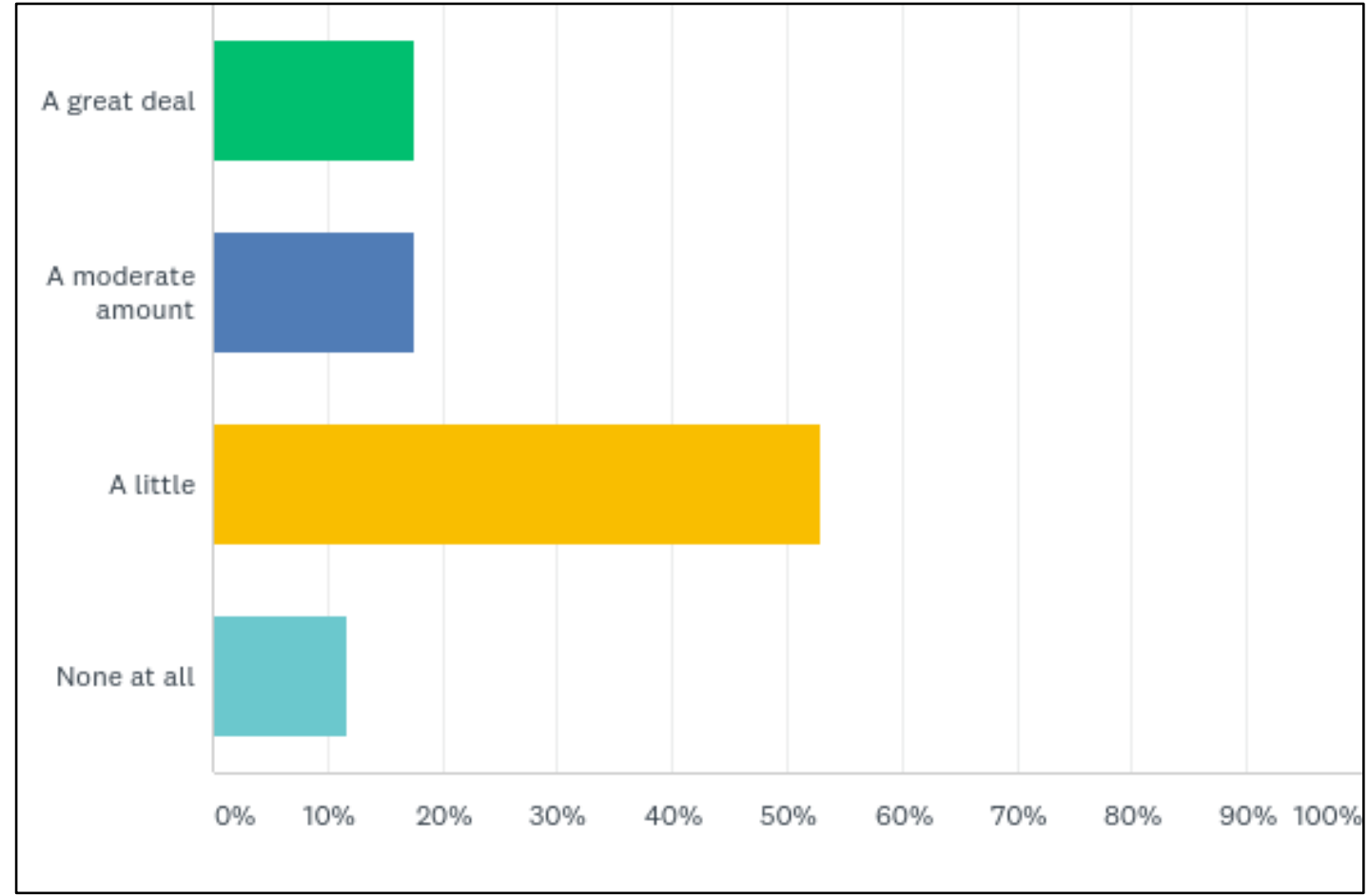

In summary, this Bangladesh-based study finds limited consultation and engagement with local communities and Indigenous people in Bangladesh during the implementation of RJ. While a feasibility study was conducted by GIZ Bangladesh before the formal launch of RJ, the document was unobtainable. More clarity about who was invited or uninvited to stakeholder engagement sessions, and what the concerns were and how they were addressed, would have increased the understanding of consultation around RJ in Bangladesh. As Cunneen suggests, (1997 p. 295), "the absence of consultation and negotiation can fundamentally compromise" the development of RJ practices.

\section{Cultural Relevance}

Culturally relevant justice practices tend to have more success. For Cunneen (1997), the idea that all Indigenous people are homologous is an invalid assumption. Therefore, a practice developed by a particular Indigenous community cannot be operationalized in other settings. "Cultural differences are inadequately dealt with" in the RJ intervention, especially for FGC in 
Australia (Cunneen, 1997, p. 295). Dodson (1996) argues that New Zealand FGC had its specific cultural reference, and its adaptation for Australia failed to account for the cultural nuances of Aboriginal peoples in Australia. Blagg (1997) expresses concern over the FGC's ability to address the needs of Aboriginal people in Australia because it excludes ceremonies; he also questions whether the concept of shame in FGC or the (police-run) Wagga Wagga model aligns with the peoples' view and understanding. He concludes that a 'franchised' RJ process is not conducive to restoration and healing; Australia's Aboriginal people need a process grounded in their values, ceremonies, and song lines (Blagg, 1997).

FGC has oft been cited as the "culturally appropriate and empowering" RJ Intervention for New Zealand's Māori people (Moyle \& Tauri, 2016, p. 88). Yet, empirical evidence to support this claim is scant (Moyle \& Tauri, 2016; Tauri, 1998, 1999). The cultural appropriateness of FGCs has been questioned because most FGCs were held in Social Welfare offices rather than on a maraei, therefore empowering "lawyers, social workers and police officers" not Māori people (Tauri, 1999, p. 159). Consequently, several studies conclude that FGCs failed Māori people (Moyle \& Tauri, 2016; Tauri, 1998, 1999). Dissatisfaction with FGC was expressed by many Māori participants, one of whom reported that "family group conferencing was never a Māori process [...] the Pākehāii appropriated the whānau hui iii, colonized it and then cheekily sold it back to the native" (Moyle \& Tauri, 2016, p. 97).

In the context of Bangladesh, some key informant interviewees expressed positive regard for RJ. BD 6 contended that RJ values such as respect, connections and relationships are in line with Bengali values and culture. More importantly, according to BD 6:

$R J$ is like another form of alternative dispute resolutions such as salish. So, the term, RJ, is new in Bangladesh but the concept of resolving conflict outside the court process is not new in Bengali culture. Salish or resolving conflict in community is deeply embedded in Bangladeshi culture. That is why people accepted the concept of RJ quickly.

$\mathrm{BD} 4$ suggested that introducing $\mathrm{RJ}$ was like "reinventing the wheel in Bangladesh":

Bangladesh has a long history of salish. Our ancestors practised this conflict resolution method for centuries. $R J$ is not 
relevant with our history. The reputation of Bangladesh's salish is well-known. People from our neighbouring countries come and get training from our salish. I wish $R J$ advocates in Bangladesh would have invested resources on salish instead of introducing RJ. Frankly speaking, I don't see much difference between $R J$ and NGO-led salish. If you ask any $R J$ coordinator in Bangladesh about their understating of $R J$ and salish, I am sure they will find it difficult to distinguish.

Survey respondents also shared similar insights to those of BD 4 . When responding to the statement "RJ is locally rooted", almost $80 \%$ of participants disagreed with the statement, while almost $88 \%$ considered salish a 'locally rooted' practice in Bangladesh (see Table 2). Therefore, it is understood from both key-informant interviewees and survey respondents that the current restorative justice practice in Bangladesh is not rooted in local culture and traditions.

Table 2. Opinion on Whether $R J$, Salish and Village Courts in Bangladesh are Locally Rooted

\begin{tabular}{|l|l|l|l|l|}
\hline Practices & Strongly Agree & Agree & Disagree & $\begin{array}{l}\text { Strongly } \\
\text { Disagree }\end{array}$ \\
\hline RJ & $0.00 \%$ & $17.65 \%$ & $52.94 \%$ & $29.41 \%$ \\
\hline Salish & $41.18 \%$ & $47.06 \%$ & $5.88 \%$ & $5.88 \%$ \\
\hline Village Courts & $5.88 \%$ & $88.24 \%$ & $5.88 \%$ & $0.00 \%$ \\
\hline
\end{tabular}

In summary, this study concludes that RJ in Bangladesh is not locally grounded in or fully contextualized to Bangladeshi history. Locating RJ in a locally rooted, culturally and historically relevant practice would have increased the depth and sustainability of RJ practices in Bangladesh. As BD 1 put it, strengthening salish would have been preferable:

I have been working in the development field for the last 30 years. What I have learned is that copying and pasting ideas from the Western world to other parts of the world does not work. People in Bangladesh are not familiar with RJ. It is a good concept, but it did not originate locally. Our local practice is salish. I did not like the way INGOs brought experts from UK and Australia and created RJ manuals so quickly and implemented it. In this way, community buy-in is seriously 
compromised. I think it is more of like INGO-imposed RJ. It would have been better if we promoted and strengthened our own salish rather than $R J$.

\section{Resource Sharing}

Another issue raised in the context of decolonizing RJ is resource sharing. Several scholars argue that sharing resources with local communities is empowering because resource extraction from colonized land was part and parcel of colonization (Tauri, 2016). Spoonley (1993) mentions that Māori communities had a significant lack of resources. Tauri (1999) also notes that very little has been done to allocate resources for Māori people even though partnership, participation, and protection are enshrined in the Treaty of Waitangi.

In the context of this study, some interviewees shared their concern over insufficient funding. For example, BD 4 expressed serious concern about the suitability of RJ because "funding [by INGOs] is slowly shrinking". BD 3 expressed serious concern about INGO resource allocations:

I know INGOs spend a lot of money on government officials, not for communities. The reason, they spend huge resources on government officials so that they [INGOs] can get approval from government. Sending government officials to expensive trips to different parts of the world is a common practice.

Aside from financial and logistical resources, there is a dearth of published articles, books, and resources in Bengali. When survey participants were asked about the availability of books, resources, and translated works on RJ in Bengali, an overwhelming majority - almost 90\% of respondents (see Figure 3) - commented on the shortage. 


\section{Figure 3. Opinion on availability of books, resources, and translated works on Restorative Justice in Bengali}

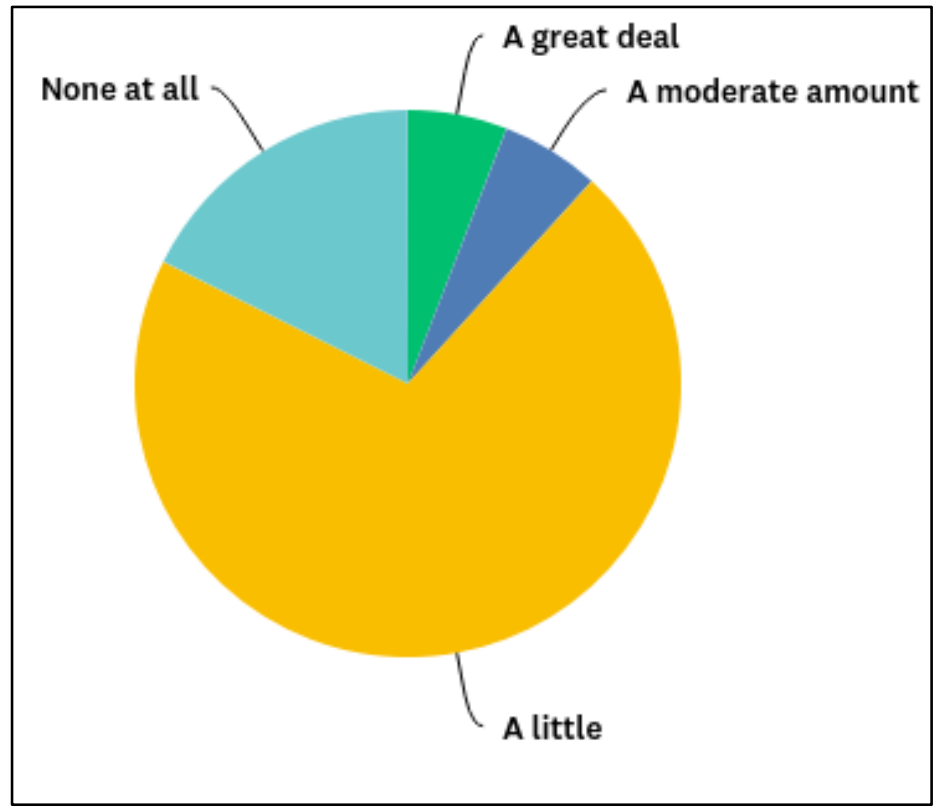

It is imperative that Bangladesh publish books and resources in Bengali and make translations of English works available, as the majority of the population does not know English (BD 2). González and Buth (2019) summarize the pervasive power imbalance created by barriers around language, another key component of the colonial system:

Despite the prescriptive theoretical vision of restorative justice as a movement grounded in disrupting social structures and promoting inclusivity, we assert there is a small group of individuals and organizations that exercise power and control over the language of restorative justice. (pp. 9-10)

In summary, similar to the findings of Cunneen (2002) for Australia and Tauri (1999) for New Zealand, this present study reveals consultation with local communities and Indigenous people during the implementation of $\mathrm{RJ}$ in Bangladesh was very limited. As well, NGO-led salish is more culturally relevant than the current model of RJ practised in Bangladesh. As such, the growth of restorative justice in Bangladesh is not locally rooted. This study recommends that rather than "reinventing the wheel" (BD 4), there be international support of NGO-led salish practices in Bangladesh, approaches such as the practice of Pukhtoon Jirga at the border of Afghanistan and Pakistan (Yousufzai \& Gohar, 2005) or Māori justice 
practices in New Zealand. After interviewing more than 50 Māori Elders, Tauri and Morris (1997) concluded that Māori justice practices constitute a more contextually, culturally and spiritually conducive form of restorative justice than did state-implemented FGCs. In these settings, it was not simply copying and pasting an RJ model; rather, available existing practices were explored and local knowledge and wisdom prioritized. As a result, community-based justice practices became locally vested and culturally relevant. In contrast, in the absence of meaningful consultations, imposed RJ practices will not only fail but also "hurt" (Strang \& Sherman, 2015, p. 10).

The following subsection proposes a decolonizing framework for RJ in Bangladesh.

\section{Proposed Decolonizing Framework for RJ}

This study proposes a decolonizing framework for RJ (Figure 4 and Table 3) conceptualized in a Tree diagram. The roots are grounded in the do-no-harm principle, a trauma-informed approach, and an anti-oppressive framework. Local or Indigenous experts and leadership form the trunk, and the branches denote actual Indigenous justice practices from around the world. With such inspiration and guidance, this version of a decolonizing framework will bear contextually, culturally, and socially appropriate fruit (i.e., RJ practices aligned with their community of practice). 
Figure 4. Decolonizing Framework for $R \boldsymbol{J}$

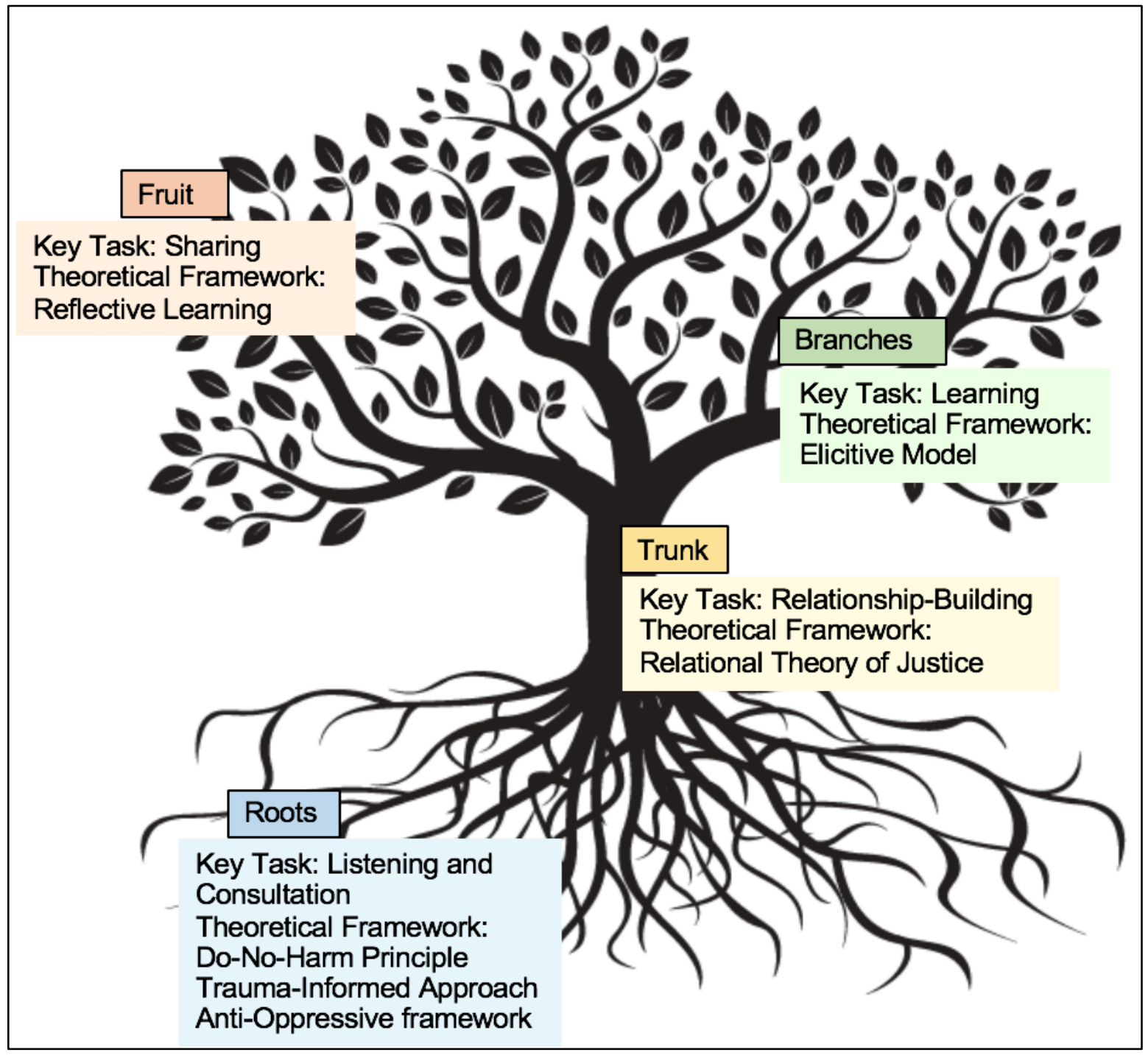

The following section discusses the Decolonizing Tree in detail.

\section{Roots}

The foundation of this decolonizing approach to RJ includes the do-no-harm principle, a trauma-informed approach and an anti-oppressive framework. Identifying and exploring existing community practices and needs are a significant part of the listening and consultation required in this phase. 


\section{$\underline{\text { Key Task: Listening and Consultation }}$}

Listening to Indigenous peoples and local communities is a process of knowledge re-creation necessary for the development and growth of RJ. The theoretical frameworks expressed by the roots support the necessity of listening and consultation.

\section{Theoretical Framework}

The do-no-harm principle is applied in both the field of international development (Anderson, 1999) and justice settings (Dyck, 2010; Pranis, 2007). This study suggests the principle is fundamental to any RJ work. Addressing "harms and needs" is one of the three pillars of RJ (Zehr, 2015, p. 32), while the principle of "do no further harm" is evoked by a group of RJ advocates and practitioners in British Columbia, Canada (BC RJ Charter, 2003, p. 2). With the do-no-harm principle at the foundation of RJ, unintended consequences are minimized. Both Australia and New Zealand exemplify how RJ can "backfire" (Strang \& Sherman, 2015, p. 10). A traumainformed approach is also integral to the do-no-harm principle.

A trauma-informed approach implies an acknowledgement of a possible or likely history of trauma. Several scholars argue that this acknowledgement contributes to healing and transformation in $\mathrm{RJ}$, as conflicts and crime are deeply rooted in unacknowledged/unhealed trauma (Crosby, 2016). A system is trauma-informed when it 1) fathoms the widespread impact of trauma and perceives potential paths for recovery; 2) recognizes the signs and symptoms of trauma in clients, families, staff, and other stakeholders; 3) has trauma-informed policies, procedures and practices; and 4) actively resists re-traumatization. There are four guiding principles of a trauma-informed approach: 1) trauma awareness, 2) safety and trustworthiness, 3) choice, collaboration and connection, and 4) strengths- and skills-building (Trauma-informed Practice Guide, 2013). According to Oudshoorn (2015), by acknowledging the harm, traumainformed justice recognizes the fact that traumatized individuals need support and helps them realize this. More importantly, trauma-informed justice focuses on healing instead of punishment and positively impacts public safety (Oudshoorn, 2015). Buffington et al. (2010) maintain that trauma-informed justice promotes healing, support, and connection and is mindful of the risk of doing more harm. Collaboration and mutual respect and partnerships among stakeholders, such as youth, families, justice 
professionals, and community practitioners, are thus necessary components of trauma-informed youth justice. Trauma-informed justice practices are reflective, evidence-based, and feedback informed, promoting a continuous cycle of learning (Buffington et al., 2010). This study argues that using the do-no-harm principle and a trauma-informed approach is critical to a decolonizing framework for RJ.

The anti-oppressive component of the roots of the decolonizing tree is considered instrumental. It is defined as "a methodology focusing on both process and outcome, and a way of structuring relationships between individuals that aims to empower users by reducing the negative effects of hierarchy in their immediate interaction and the work they do together" (Dominelli, 2002, p. 6). It challenges colonial "power relations" still embedded in the criminal justice system of nation-states (Cassell, 2014, p. 7). Van Wormer (2006) argues that RJ is "decidedly anti-oppressive in that it gives voice to persons who traditionally have been silenced in the courtroom" (p. 66). Healy (2005) prescribes five principles for an antioppressive framework: 1) critical self-reflection in practice, 2) critical assessment of service users' experiences of oppression, 3) empowerment, 4) partnership, and 5) minimal intervention.

In summary, the do-no-harm principle, a trauma-informed approach, and an anti-oppressive framework would contribute to the foundation of a decolonization method for RJ practices, particularly in community settings such as in Bangladesh, and they form the roots of the Decolonizing RJ Tree.

\section{Trunk}

Local and Indigenous peoples comprise the trunk. The knowledge and wisdom of these experts and leaders make them key to RJ's decolonizing framework. Keeping local and Indigenous experts at the heart will engender a locally grounded practice. Yellow Bird (2014), Monchalin (2016), and Leeuw and Hunt (2018) all underscore the importance of leadership by local community members.

\section{Key Task: Relationship-Building}

As a result of listening and meaningful consultation with Indigenous people and local communities, a 'relation' arises. The key stakeholders in this phase are the Indigenous people and local communities. 


\section{Theoretical Framework: Relational Theory of Justice}

According to Llewellyn et al. (2013, p. 295), "Restorative justice is best understood as a relational theory of justice [RTJ]". RTJ focuses not only on the wrongs and harms but also on the relational impact of wrongdoings on the individual, group, and community, nationally and internationally. RTJ can also address harms in issues of human rights and labour relations (Llewellyn et al., 2013, p. 298). Injustices and wrongdoings, according to Llewellyn (2011, p. 95), are defined as the "existence of inequality of relationship between and among individuals, groups, and communities." In this approach, conflicts or crimes are seen to cause harm not only to personal or direct relationships but also to "webs of relationships and to the society at large" (Llewellyn, 2011, p. 97). In other words, crime, in the relational theory of justice, is a violation of relationships (Pranis, 2007).

According to this theory, the goal of any society's justice mechanism is both the protection and creation of relationships. Interconnectedness and interdependency are fundamental to a relational approach to justice:

we are not independent from one another and our autonomy and freedom is not found in separation from one another. We are instead interdependent and our freedom relies on mutual construction and the support of others. Wrong is understood in relational terms as well-as that which results in harms to individuals and the relationships in and through which they live. Understanding and addressing wrongs (the work of justice), then, requires attention to these relationships and how they might be restored. (Llewellyn \& Philpott, 2014, p. 17)

Equality of relationship is the foundation of the relational justice approach (Llewellyn, 2011) and equality of respect, dignity and mutual concern for all parties-victims, perpetrators, communities and justice stakeholders-are the specific principles and criteria. Respect in relational justice theory implies recognition of the rights and needs of others, while dignity connotes the needs and interests of those caught up in the justice mechanism. It also refers to the relational impact of one's actions on others. Finally, concern prioritizes the knowledge, interests and wellbeing of all parties. The relational approach to justice is relationship-centric, inclusive, participatory and holistic (Llewellyn, 2011; Llewellyn \& Philpott, 2014). 
Llewellyn and colleagues (2013, p. 301) outline several principles for RTJ in the context of RJ, such as 1) relationship focused; 2) comprehensive/holistic; 3) contextual/flexible; 3) subsidiarityiv, inclusion, and participation; 4) dialogical or communicative; 5) democratic/deliberative; 6) forward-focused, solution-focused, and remedial. More importantly, RTJ is deeply

rooted in a broader relational theory of the world as more than a factual description of the ways in which we live. In this way it is informed by and deeply resonates with Indigenous ways of knowing and seeing the world (Llewellyn \& Morrison, 2018, p. 347).

This study postulates that a relational framework for RJ (RTJ) would contribute to the creation of just relationships between and among local communities, INGOs and government officials.

\section{Branches}

Locally grown Indigenous justice practices and grassroots wisdom around the world are the sources of inspiration and guidance for the proposed RJdecolonizing framework. Maori justice practices (Tauri \& Morris, 1997) and the Chakma Justice System (Asadullah, 2013) are suitable examples.

\section{Key Task: Learning}

This study asserts that learning about best practices from around the world would guide NGOs, INGOs and local communities to find an intervention that is culturally and socially relevant. For example, RJ advocates in Nepal may choose to explore such practices in other South Asian countries. The key task in this phase is learning from community praxis across somewhat familiar cultural and social settings.

\section{Theoretical Framework: Elicitive Model}

Even though it was developed in the context of peacebuilding, Lederach's "elicitive model" can be utilized as a theoretical framework to foster a comprehensive learning framework for local communities, INGOs and other justice stakeholders in developing RJ practices. Lederach (2001) defines the elicitive model as tying conflict to individual cultures and contexts. Designing “appropriate response mechanisms" (p. 79) requires a capacity to 
draw out peoples' understanding of their context and culture, as well as introducing new ideas. It parallels Latin America's concept of 'popular education' and is similar to Paulo Freire's participatory-education pedagogy, as opposed to one-way knowledge transfers from expert to student.

Another important feature of the elicitive model is that it is nonhierarchic, making the researcher more of "a catalyst and a facilitator" than an "expert" and knowledge producer (Lederach, 1995, p. 56). All participants are viewed as "resources not recipients" in this model (Shank \& Schirch, 2008, p. 232). Both culturally and contextually specific knowledge is foundational to this approach. More importantly, participants share responsibility, learn from each other's experience, and are involved in critical thinking. As a result, they co-create knowledge and contribute to innovative practices and ideas (Abu-Nimer, 2001; Shank \& Schirch, 2008). The transformative inquiry paradigm by Toews and Zehr (2003) identifies ten principles that substantiate the elicitive model. Of these, the most important two prescribe that the process be more emphasized than the outcome and that participants be considered active subjects (Toews $\&$ Zehr, 2003). In this way, the elicitive model incorporates Zehr's 3 Rs - Respect, Responsibility, and Relationship (Zehr, 2015) - to foster innovation.

\section{Fruit}

Justice practices ensuing from this decolonizing framework will be contextually, culturally, socially, and spiritually conducive to the restoration of relationships and healing. As Zehr (2015) suggests, all RJ practices "should be built from the bottom up, by communities, through dialogue, assessing their needs and resources, and applying the principles to their own situations" (p. 17).

\section{Key Task: Sharing}

According to this study, once communities obtain a locally grown and culturally relevant practice, they will be masters of their process. Further, the adoption of a trauma-informed approach and anti-oppressive framework leading to socially and culturally sensitive RJ practices is dependent on leadership from local justice stakeholders coupled with lessons from best practices across somewhat similar cultural settings. A good example of this is found in Pukhtoon Jirga at the border of Afghanistan and Pakistan (Yousufzai \& Gohar, 2005). 


\section{Theoretical Framework: Reflective Practice}

The concept of reflective practice has been useful for peacebuilding and consists of theory and practice. According to Lederach and colleagues (2007), the process of reflective practice is defined by "demystifying theory and remystifying practice" (p. 3). In a reflective-practice framework, theory is also explored through a practitioner's lens.

Theory should not be approached as abstract and intellectually difficult, for academics only. In fact, theory is straightforward: a theory is an assumption about how something works, or a prediction of what will happen as a result of an action (Lederach et al., 2007, pp. 3-4).

Remystifying practice implies the process of "sharpening capacities that are too often left unattended" (Lederach et al., 2007, p. 4) by a) always asking why; b) when you ask why, listen for 'because'; c) learn from failure; d) watch carefully for the unexpected; and e) discuss your projects with different people (Lederach et al., 2007, p. 5). In short, reflective practice is driven by both theory and practice, and local communities must be given the lead. Additionally, the reflection on theory and practice supports continuous learning. In this way, locally grown practice will not remain static but will continue to evolve and flourish.

The task, theoretical framework, and expected results of each component of the Decolonizing RJ Framework are summarized in Table 3. 
Table 3. Decolonizing RJ Framework

\begin{tabular}{|c|c|c|c|}
\hline & Main Task & $\begin{array}{l}\text { Theoretical } \\
\text { Framework }\end{array}$ & Expected Results \\
\hline Root & $\begin{array}{l}\text { INGOs and RJ proponents } \\
\text { need to listen and } \\
\text { conduct meaningful } \\
\text { consultations with } \\
\text { Indigenous peoples and } \\
\text { the local community. }\end{array}$ & $\begin{array}{l}\text { Do No Harm } \\
\text { Principle } \\
\text { Trauma-Informed } \\
\text { Approach } \\
\text { Anti-Oppressive } \\
\text { Framework }\end{array}$ & $\begin{array}{l}\text { Resource distributions to } \\
\text { Indigenous Peoples and } \\
\text { local communities; } \\
\text { Translations of RJ best } \\
\text { practices. }\end{array}$ \\
\hline Trunk & $\begin{array}{l}\text { Grounded on local } \\
\text { tradition and cultures, } \\
\text { INGOs, Government } \\
\text { Agencies and CBOs need } \\
\text { to build relationships } \\
\text { with the Indigenous } \\
\text { people and local } \\
\text { community. }\end{array}$ & $\begin{array}{l}\text { Relational Theory } \\
\text { of Justice }\end{array}$ & $\begin{array}{l}\text { Collaboration and } \\
\text { partnerships under the } \\
\text { leadership of Indigenous } \\
\text { Peoples and local } \\
\text { communities }\end{array}$ \\
\hline Branches & $\begin{array}{l}\text { Learning about culturally } \\
\text { similar RJ practices from } \\
\text { around the world. }\end{array}$ & Elicitive Model & $\begin{array}{l}\text { Exploring, imagining and } \\
\text { evolving locally grown RJ } \\
\text { practices }\end{array}$ \\
\hline Fruit & $\begin{array}{l}\text { Sharing the practices } \\
\text { with those who are in } \\
\text { need. }\end{array}$ & $\begin{array}{l}\text { Reflective } \\
\text { Practice: cyclical } \\
\text { learning, } \\
\text { reflection and } \\
\text { relearning. }\end{array}$ & $\begin{array}{l}\text { Locally grown, and locally } \\
\text { owned, culturally relevant } \\
\text { RJ practices }\end{array}$ \\
\hline
\end{tabular}

In the proposed decolonizing framework, listening and meaningful consultation will play an important role along with sharing resources with local communities. More importantly, local knowledge, expertise, and leadership are instrumental to this decolonizing framework and a number of theoretical frameworks offer integral support to each phase.

\section{Conclusion}

Grounded in the findings of research participants and the work of Cunneen, (2002), Monchalin (2016), and Tauri and Morris (1997), this study proposes a decolonizing framework for RJ practices, in particular for Bangladesh. Framed by a tree format, this decolonization model has four key components - 1) roots, 2) trunk, 3) branches, and 4) fruits. The roots convey the traumainformed and anti-oppressive foundation of this framework. Key tasks for 'root' development are active listening and consultation. The trunk embodies local knowledge and leadership, with relationship building as the phase's 
key task. The branches denote culturally and socially relevant justice practices across similar settings. The fruits in this 'Decolonizing Framework for RJ' are a by-product, reflective learning from theory and practice, and sharing with those in need.

To bring a decolonizing framework to the development of $\mathrm{RJ}$ in Bangladesh, RJ visionaries and advocates in Bangladesh need to reimagine and explore traditional justice practices that have been lost due to colonization. At the same time, Bangladesh's justice practitioners must avoid what Dunn (2013, p. 96) called romanticization of traditional and customary justice practices, some of which had harmful impacts on some segments of the community. Likewise, the origins of some past practices may not be "traditional." For example, Fanon argued that "the 'traditional' culture which Algerians thought they were trying to protect against colonial imposition, and a concomitant resistance to 'European' science and technical knowledge, were not cultural particularities to be celebrated, but reactionary impulses induced by the colonial system" (cited in Etherington, 2016, p. 163). Thus, a balanced and more nuanced approach is crucial in this regard. This study suggests that proper consultations with local justice stakeholders, resources sharing with local communities and stewardship of community-based justice organizations are instrumental for decolonizing restorative justice practices in Bangladesh.

In summary, this study proposes that the adoption of a traumainformed approach and anti-oppressive framework that involves the leadership of local justice stakeholders coupled with lessons from best practices across somewhat similar cultural settings would result in socially and culturally aligned, culturally responsive decolonizing RJ practices.

\section{References}

Abu-Nimer, M. (2001). Conflict resolution, vulture, and religion: Toward a training model of interreligious peacebuilding. Journal of Peace Research, 38(6), 685-704.

Alfred, T. (2009). Restitution is the real pathway to justice for Indigenous Peoples. In G. Younging, J. Dewar, \& M. DeGagné (Eds.), Response, responsibility, and renewal: Canada's truth and reconciliation journey (pp. 181-187). Aboriginal Healing Foundation.

Anderson, M. (1999). Do no harm: How aid can support peace or war. Lynne Rienner Publishers. 
Asadullah, M. (2020). Community praxis: Exploring a community engagement framework for restorative justice in British Columbia, Nova Scotia, and Bangladesh. Journal of Community Safety and WellBeing, 5(3), 110-119.

Asadullah, M. (2013). Indigenous justice system in the Chittagong Hill Tracts: An exploratory listening project in Bangladesh. Alaska Journal of Dispute Resolution, 2013(1), 87-100.

Asaduzzaman, S. M. (2014). Rethinking community-based justice system for conflict transformation: An action research reflections from Bangladesh on local justice and peacebuilding. LAP Lambert Academic Publishing.

Battiste, M. (2013). Decolonizing education: Nourishing the learning spirit. Purich.

BC RJ Charter. (2003). A charter for practitioner of restorative justice. Centre for Restorative Justice, Simon Fraser University, Burnaby, BC, Canada.

Bhattacharya, K. (2018). Learning decolonizing methodologies in qualitative research [Video file]. Retrieved from SAGE Research Methods.

Bird, M. Y. (2014, February 18). Dr. Michael Yellow Bird on 'Healing through neurodecolonization and mindfulness' [Video file] Retrieved Jul 3, 2019 from https: / / vimeo.com/86995336

Blagg, (2017). Doing restorative justice 'otherwise': Decolonising practices in the Global South. In I. Aertsen \& B. Pali (Eds.) Critical Restorative Justice. Hart. DOI:10.5040/9781509906659.ch-004

Blagg, H. (2008). Colonial critique and critical criminology: Issues in aboriginal law and aboriginal violence. In T. Anthony \& C. Cunneen (Eds.), The critical criminology companion (pp. 129-143). Hawkins Press.

Blagg, H. (1997). A just measure of shame? Aboriginal youth and conferencing in Australia. British Journal of Criminology, 37(4), 481501.

Blagg, H., \& Anthony, T. (2019). Decolonising criminology: Imagining justice in a postcolonial world. Palgrave Macmillan.

Braun, V., \& Clarke, V. (2013). Successful qualitative research. Sage.

Breton, D. (2011). Decolonizing restorative justice, unsettling America: Decolonization in theory and practice. Available at https://unsettlingamerica.wordpress.com/2011/09/13/decolonizin g-restorative-justice/ 
Buffington, K., Dierkhising, C., \& Marsh, S. (2010). Ten things every juvenile court judge should know about trauma and delinquency. Juvenile \& Family Court Journal, 61(3), 13-23.

Carrington, K., Hogg, R., \& Sozzo, M. (2016). Southern criminology. The British Journal of Criminology, 56(1), 1-20.

Cassell, J. (2014). Impacts of restorative justice on youth in conflict with the law: A narrative approach. (Master of Social Work). Program of Social Work, Ryerson University.

Crosby, S. D. (2016). Trauma-informed approaches to juvenile justice: A critical race perspective. Juvenile and Family Court Journal, 5-18.

Cunneen, C. (2006). Racism, discrimination and the over-representation of Indigenous people in the criminal justice system: Some conceptual and explanatory issues. Current Issues in Criminal Justice. 17(3), 329346.

Cunneen, C. (2002). Restorative justice and the politics of decolonization. In E. G. M. Weitekamp \& H.-J. Kerner (Eds.) Restorative justice: Theoretical foundations (pp. 32-49). Willan.

Cunneen, C. (1997). Community conferencing and the fiction of indigenous control. Australian \& New Zealand Journal of Criminology, 30(3), 292311.

Denzin, K. N., \& Lincoln, S. Y. (2013). Collecting and interpreting qualitative materials. SAGE Publications.

Dodson, M. (1996). Aboriginal and Torres Strait Islander Social Justice Commissioner Fourth Report, AGPS, Canberra. Available at https://www.humanrights.gov.au/our-work/ Indigenous -deathscustody

Dominelli, L. (2002). Anti-oppressive practice in context (2nd edition). In R. Adams, L. Dominelli \& M. Payne (Eds.) Social work: Themes, issues and critical debates (pp. 1-19). Palgrave.

Dunn, H. (2013). Customary justice and the rule of law in the eastern DRC: A case study of Baraza. [Master's thesis, Carleton University, Canada]. Available at https://curve.carleton.ca/1f79275d-cd92-4751-b910e2ceaef2e8f7

Dyck, D. (2010). Are we - practitioners, advocates - practicing what we preach? In H. Zehr and B. Toews (Eds.) Critical issues in restorative justice (pp. 277-291). Lynn Rienner Publishers. 
Etherington, B. (2016). An answer to the question: What is decolonization? Frantz Fanon's the wretched of the earth and Jean-Paul Sartre's critique dialectical reason. Modern Intellectual History, 13(1), 151-178.

Fanon, F. (1963). The wretched of the earth. Grove Press.

Gentles, S. J., Charles, C., Ploeg, J., \& McKibbon, K. (2015). Sampling in qualitative research: Insights from an overview of the methods literature. The Qualitative Report, 20(11), 1772-1789.

GIZ. (2014, October). Improvement of the real situation of overcrowding in prisons in Bangladesh (IRSOP). We have not forgotten you: New pathways for prisoners. Deutsche Gesellschaft für Internationale Zusammenarbeit.

González, T., \& Buth, J. A. (2019). Restorative justice at the crossroads: Politics, power, and language, Contemporary Justice Review, DOI: 10.1080/10282580.2019.1644172.

Goulding, D., Steels, B., \& McGarty, C. (2016). A cross-cultural research experience: Developing an appropriate methodology that respectfully incorporates both Indigenous and non-Indigenous knowledge systems. Ethnic and Racial Studies, 39(5), 783-801.

Hand, C. A., Hankes, J., \& House, T. (2012). Restorative justice: The Indigenous justice system. Contemporary Justice Review, 15(4), 449467.

Healy, K. (2005). Social work theories in context. Palgrave Macmillan.

Jacobs, B. (2017). Decolonizing the violence against Indigenous women. In P. McFarlane \& N. Schabus (Eds.) Whose land is it anyway? (pp. 4751). Federation of Post-Secondary Educators of BC, BC, Canada.

Kvale, S., \& Brinkman, S. (2009). Interviews: Learning the craft of qualitative Interviewing. Sage.

Laboucan-Massimo, M. (2017). Lessons from Wisahkecahk. In P. McFarlane $\&$ N. Schabus (Eds.) Whose land is it anyway? (pp. 36-41). Federation of Post-Secondary Educators of BC, BC, Canada.

Lederach, J. P. (2001). The heart of reconciliation: A conversation with John Paul Lederach. (B. Kruschwitz, Interviewer). Available at https://www.baylor.edu/ifl/christianreflection/Forgivenessinterview Lederach.pdf

Lederach, J. P. (1995). Preparing for peace: Conflict transformation across cultures. Syracuse University Press. 
Lederach, J. P., Neufeldt, R., \& Culbertson, H. (2007). Reflective peacebuilding: A planning,monitoring and learning toolkit. The Joan B.Kroc Institute for International Peace Studies, University of Notre Dame and Catholic Relief Services.

Leeuw, D. S., \& Hunt, S. (2018). Unsettling decolonizing geographies. Geography Compass, 12(7), 1-14.

Llewellyn, J. (2011). Restorative justice: Thinking relationally about Justice. In J. Downie and J. Llewellyn (Eds.) Being relational: Reflections on relational theory and health law. (pp. 89-108). UBC Press.

Llewellyn, J., Archibald, B., Clairmont, D., \& Crocker, D. (2013). Imagining success for a restorative approach to justice: Implications for measurement and evaluation. Dalhousie Law Journal, 36(2), 281-316.

Llewellyn, J., \& Morrison, B. (2018). Deepening the relational ecology of restorative justice. The International Journal of Restorative Justice, 1(3), 343-355.

Llewellyn, J. J., \& Philpott, D. (2014). Restorative justice, reconciliation, and peacebuilding. Oxford University Press.

Manuel, K. (2017). Decolonization: The frontline struggle. In P. McFarlane and N. Schabus (Eds.), Whose land is it anyway? (pp. 42-46). Federation of Post-Secondary Educators of BC, BC, Canada.

Matsunaga, J. (2016). Two faces of transitional justice: Theorizing the incommensurability of transitional justice and decolonization in Canada, Decolonization: Indigeneity, Education \& Society 5(1), 24-44.

McGuire. M., \& Palys, T. (2020). Toward sovereign Indigenous justice: On removing the colonial straitjacket. Decolonization of Criminology and Justice, 2(1), 59-82.

McMillan, C. (2018). Navigating emotions while establishing trust and rapport in autoethnography. In S.W. Kleinknecht, L. K. van den Scott $\&$ C.B. Sanders (Eds.) The craft of qualitative research (pp.114-120). Canadian Scholars' Press.

McNamara, R., \& Naepi, S. (2018). Decolonizing community psychology by supporting Indigenous knowledge, projects, and students: Lessons from Aotearoa New Zealand and Canada. American Journal of Community Psychology, 62(3-4), 340-349.

Monchalin, L. (2016). The colonial problem: An indigenous perspective on crime and injustice in Canada. University of Toronto Press.

Moyle, P., \& Tauri, J. (2016). Māori, family group conferencing and the mystifications of restorative justice. Victims \& Offenders, 11(1), 1-20. 
Ngũgĩ, W. T. (1986). Decolonising the mind: The politics of language in African literature. Heinemann.

Ninomiya, M. M., Hurley, N., \& Penashue, J. (2018). A decolonizing method of inquiry: Using institutional ethnography to facilitate communitybased research and knowledge translation. Critical Public Health, $30(2), 1-12$.

Oudshoorn, J. (2015). Trauma-informed youth justice in Canada: A new framework toward a kinder future. Canadian Scholars' Press.

Paris, D., \& Winn, M. (2014). Humanizing research: Decolonizing qualitative inquiry with youth and communities. Sage.

Park, A. (2016). Remembering the children: Decolonizing community-based restorative justice for Indian Residential Schools. Contemporary Justice Review 19(4), 424-444.

Pranis, K. (2007). Restorative values. In G. Johnstone \& D. W. Van Ness (Eds.) Handbook of restorative justice (pp. 59-74). Willan.

Reconciliation Canada. (n.d.). Chief Dr. Robert Joseph. Available at https: / / reconciliationcanada.ca/about/team/chief-dr-robertjoseph/

Regan, P. (2010). Unsettling the settler within: Indian Residential Schools, truth telling, and reconciliation in Canada. UBC Press.

Said, E. (1978). Orientalism. Pantheon Books.

Sellars, B. (2017). Preface. In P. McFarlane \& N. Schabus (Eds.) Whose land is it anyway? (pp. 6-8). Federation of Post-Secondary Educators of BC, $\mathrm{BC}$, Canada.

Shank, M. \& Schirch, L. (2008). Strategic arts-based peace-building. Peace and Change, 33(2), 217-242.

Shepard, T. (2006). The invention of decolonization: The Algerian war and the remaking of France. Cornell University Press.

Smith, L. T. (2012). Decolonizing methodologies: Research and indigenous peoples. Zed Books.

Spoonley, P. (1993). Racism and ethnicity. Oxford University Press.

Stewart, M. (2018). Racialized policing: Settler colonialism and justice. In M. Hurlbert (Ed.) Pursuing justice: An introduction to justice studies (pp. 180-198). Fernwood Publishing.

Strang, H., \& Sherman, L. (2015). The morality of evidence: The second annual lecture for restorative justice. Restorative Justice: An International Journal, 3(1), 6-27. 
Tauri, J. (2016). Indigenous peoples and the globalization of restorative justice. Social Justice, 43(3), 46-67.

Tauri, J. (1999). Explaining recent innovations in New Zealand's criminal justice system: Empowering Māori or biculturalising the state? Australian and New Zealand Journal of Criminology, 32(2), 153-167.

Tauri, J. (1998). Family group conferencing: A case study of the indigenisation of New Zealand's justice system. Current Issues in Criminal Justice, 10(2), 168-182.

Tauri, J., \& Morris, A. (1997). Re-forming justice: The potential of Māori processes. Australian and New Zealand Journal of Criminology, 30(2), 149-167.

The Daily Star. (2015, June 20). Three million cases pending. Available at https://www.thedailystar.net/editorial/three-million-cases-pending99781.

Toews, B., \& Zehr, H. (2003). Ways of knowing for a restorative worldview. In E. G. Weitekamp, \& H.-J. Kerner (Eds.), Restorative justice in context: International practice and directions (pp. 257-271). Willan.

Trauma-Informed Practice Guide. (2013). BC Provincial Mental Health and Substance Use Planning Council. BC, Canada. Available at http:/ / tiny.cc/r9vc9y

Tuck, E., \& Yang. K. W. (2012). Decolonization is not a metaphor. Decolonization: Indigeneity, Education \& Society, 1(1), 1-40.

Van Wormer, K. (2006). The case for restorative justice: A crucial adjunct to the social work curriculum. Journal of Teaching in Social Work, 26(3/4), 57-69.

Yin, R. K. (2011). Qualitative research from start to finish. Guilford Press.

Yousufzai, M. H., \& Gohar, A. (2005). Towards understanding Pukhtoon Jirga. Peshawar: Just Peace International.

Zehr, H. (2015). The little book of restorative justice: Revised and updated. Good Books. 
i A marae is a fenced-in complex of carved buildings and grounds that belongs to a particular iwi (tribe), hapu (sub tribe) or whānau (family). Māori people see their marae as türangawaewae - their place to stand and belong. For more information: https://www.newzealand.com/ca/feature/maraemaori-meeting-grounds

ii Pākehā refers to people of European descent.

iii whānau hui connotes a meeting by the extended family

iv subsidiarity refers to taking decisions "as closely as possible to the citizen" (European Commission in Llewellyn et al, 2013, p. 302) and involving "those with intimate knowledge of the contexts and relationships at stake" (Llewellyn and Philpott, in ibid, p. 302) 